\title{
EXOGENOUS HYDROGEN SULFIDE FOR THE TREATMENT OF MESENTERIC DAMAGE ASSOCIATED WITH FRUCTOSE-INDUCED MALFUNCTIONS VIA INHIBITION OF OXIDATIVE STRESS
}

\author{
O. REVENKO ${ }^{1 \bowtie}$, N. ZAICHKO', J. WALLACE ${ }^{3}$, O. ZAYACHKIVSKA ${ }^{1}$ \\ ${ }^{1}$ Department of Physiology, Danylo Halytskyy Lviv National Medical University, Ukraine; \\ ${ }^{2}$ Department of Biochemistry and General Chemistry, \\ National Pirogov Memorial Medical University, Vinnytsia, Ukraine; \\ ${ }^{3}$ Department of Physiology and Pharmacology, University of Calgary, Canada \\ 凶e-mail:wersus35@gmail.com
}

Received: 30 December 2019; Accepted: 27March 2020

\begin{abstract}
Remodeling of adipocytes in mesentery (AM) associated with nutritional overload from high fructose diet (HFD) is a source of several comorbidities. However, its pathogenesis is still unclear and there are no specific effective drugs for AM remodeling. Recently hydrogen sulfide $\left(\mathrm{H}_{2} \mathrm{~S}\right)$ demonstrated potent cytoprotective actions. The purpose of this study was to investigate the effects and underlying mechanisms of AM remodeling in rats fed HFD and with $\mathrm{H}_{2} \mathrm{~S}$ pre-treatment. Adult male rats on standard diet (SD, control group) or HFD that underwent acute water-immersion restraint stress (WIS) were evaluated for subcellular AM adaptive responses by electron microscopy. The effects on AM of exogenous sodium hydrosulfide (NaHS, $5.6 \mathrm{mg}$ / $\mathrm{kg} /$ day for 9 days) and the $\mathrm{H}_{2} \mathrm{~S}$-releasing aspirin (ASA) derivative $\left(\mathrm{H}_{2} \mathrm{~S}\right.$-ASA [ATB-340], $17.5 \mathrm{mg} / \mathrm{kg} /$ day) vs conventional ASA (10 mg/kg/day) vs vehicle were investigated. Serum glucose level, thiobarbituric acid reactive substances (TBARS), and activities of cystathionine $\gamma$-lyase (CSE) and cystathionine $\beta$-synthase (CBS) were examined biochemically using spectrophotometry. In the HFD groups, treatment with NaHS protected $A M$, as mesenteric microvascular endothelial and sub-endothelial structures were observed vs the vehicletreated group that had signs of endothelial dysfunction, AM damage and dysfunctional mitochondria. The effect of $\mathrm{H}_{2} \mathrm{~S}$-ASA was characterized by protection of AM against HFD and WIS-induced injury, with lower TBARS blood level and increased CSE and CBS activities. Carbohydrate overload for 4 weeks is sufficient to cause AM oxidative damage, mitochondrial dysfunction and endothelial changes. $H_{2} S$ plays an important role in mesenteric adipocyte cellular survival against HFD-induced oxidative stress by decreasing overproduction of TBARS and mitochondrial dysfunction. The use of $\mathrm{H}_{2} \mathrm{~S}$ could lead to a novel approach for anti-obesity treatment.
\end{abstract}

Ke y w ords: hydrogen sulfide $\left(\mathrm{H}_{2} \mathrm{~S}\right)$, thiobarbituric acid reactive substances (TBARS), cystathionine gamma-lyase (CSE), cystathionine beta-synthase (CBS), oxidative stress, adipocytes, mesentery, mitochondria.

\section{Introduction}

Based on the WHO data, the obesity rate in the World in 2016 reached approximately 9\% of the world's population (641 million individuals) (WHO report, 2016). The increasing incidence of obesity is a global trend related to contemporary lifestyle that is associated with an excess of dietary reducing sugars. Nutritional overload by a hypercaloric high fructose diet (HFD), causes development of ad- vanced glycation end products linked to oxygen-free radicals that are the source for several comorbidities, seriously threatening human health $[1,2]$. Proposed behavioral lifestyle interventions based on the first-line anti-obesity lifestyle strategies, including calorie-restrictive diet and increased physical activities, are not always successful since the most recent data have shown that obesity rates in the US in 2018 are $39.6 \%$ among adults and $18.5 \%$ in children, in

(C) 2020 Revenko O. et al. This is an open-access article distributed under the terms of the Creative Commons Attribution License, which permits unrestricted use, distribution, and reproduction in any medium, provided the original author and source are credited. 
Ukraine these rates are $25 \%$ and $14.4 \%$, respectively [3].

Recently, it was shown that oxidative stress related to metabolic responses linked to high carbohydrate intake can modulate DNA methylation and reduce the NAD+ dependent deacetylase SIRT1 that controls mitochondrial respiration and reactive oxygen species production, causing inflammatory responses, lipid storage, and changes in telomerase activity [4]. In this context, HFD that decreases NAD ${ }^{+}$ content can negatively regulate sirtuin activity, and could induce metaflammation (metabolic inflammation), a low-grade chronic sterile inflammation primarily driven by endogenous signals which is suggested as one of the central mechanisms of obesity. It is characterized not only by remodeling adipocyte tissue (RAT), but also by metabolic endotoxemia [5].

Mesentery, one of the separate visceral organs that recently was discovered $[6,7]$, serves functions in cross-talk of local or systemic responses via signaling pathways that play a crucial role in the induction of inflammatory factors, as well as control of glycemic and lipid metabolism [8, 9]. Among different structural elements of the mesentery, there is white adipocyte tissue. However, the understanding of early mesenteric RAT during short-term exposure to HFD is still incomplete. Moreover, what the early mechanism is for HFD-related RAT-formation in mesentery has not yet been investigated.

Recently it was shown that hyperglycemia and RAT induced decreased bioavailability of hydrogen sulfide $\left(\mathrm{H}_{2} \mathrm{~S}\right)$, a naturally occurring gas produced by various eukaryotic cells and gut microbiota that has potent vasodilator activity, anti-inflammatory, and anti-oxidant effects [10-12]. Furthermore, modification of catalytic activities of cystathionine- $\gamma$-lyase (CSE, EC 4.4.1.1) and cystathionine- $\beta$-synthase (CBS, EC 4.2.1.22) could prevent mitochondrial dysfunction and attenuate oxidative damage [1315]. Accordingly, there are reports by Wallace et al. (2015, 2017) about new pharmacologic approaches using exogenous $\mathrm{H}_{2} \mathrm{~S}$ treatment and hybrid $\mathrm{H}_{2} \mathrm{~S}$ associated non-steroidal anti-inflammatory drugs ( $\mathrm{H}_{2} \mathrm{~S}$-NSAIDs) for preventing oxidative stress, in the context of adipocytes in mesentery (AM) malfunction related to HFD, $\mathrm{H}_{2} \mathrm{~S}$ compounds could be a source for novel pharmacologic treatment of obesity [16-18]. Thus, we hypothesized that the underlying mechanisms of RAT could be a target for treatment by the exogenous $\mathrm{H}_{2} \mathrm{~S}$ donor sodium hydrosulfide (NaHS) and the novel $\mathrm{H}_{2} \mathrm{~S}-\mathrm{NSAID}$ hybrid, namely the $\mathrm{H}_{2} \mathrm{~S}$-releasing aspirin (ASA) derivative ATB-340 ( $\mathrm{H}_{2} \mathrm{~S}-\mathrm{ASA}$, 4-(5-thioxo-5H-1,2-dithiol-3-yl)phenyl 2-acetoxybenzoate).

Therefore, this study had the following objectives: (1) to define the influence of 28 days of HFD on AM and detect underlying mechanisms of the effects with a focus on the modifications of adipocyte mitochondria and activities of CBS, CSE in $\mathrm{H}_{2} \mathrm{~S}$ biosynthesis; (2) to study the role of H2S, from the effects of exogenous treatment with $\mathrm{NaHS}$ and $\mathrm{H}_{2} \mathrm{~S}$ ASA (ATB-340), on mesenteric adipocytes in rats fed for 4 weeks with HFD, in comparison with ASAand stress-associated models of injury.

\section{Materials and Methods}

Reagents. NaHS, D,L-homocysteine, Lcysteine, and $\mathrm{Na}_{2} \mathrm{~S} \cdot 9 \mathrm{H}_{2} \mathrm{O}$ were obtained from SigmaAldrich (St. Louis, MO, USA). Pyridoxal phosphate and N,N-dimethyl-para-phenylenediaminesulfate were obtained from Acros Organic (New Jersey, USA). ATB-340 was obtained from Antibe Therapeutics (Toronto, Canada). ASA was purchased from Borshchahivskiy CPP (Kyiv, Ukraine). All chemicals used in the experiments were graded by the analytical method that was validated according to the guidelines of the International Conference on Harmonization (ICH).

Animals, diets and treatments. All experiments were performed in accordance with the European Convention for the Protection of Vertebrate Animals Used for Experimental and Other Scientific Purposes (1986) and EU directive 2010/63/EU, and with the approval of the Local Ethics Committee at Danylo Halytskyy Lviv National Medical University (DHLNMU), Lviv, Ukraine (23/04/2018 № 4).

Adult male Wistar rats $(190 \pm 28 \mathrm{~g})$ were housed individually in standard cages in an animal colony room maintained at $22 \pm 2{ }^{\circ} \mathrm{C}$ and at $55 \pm 10 \%$ humidity under a 12-h light-dark cycle. All animals $(n=48)$ were kept in raised mesh-bottom cages to prevent coprophagy. Six rats were used in each group. Rats in the control group had free access to water and were kept on standard diet (SD). Animals in the experimental groups received 28 days of fructose-supplemented water (HFD), unrestricted access to a $40 \%$ solution of fructose ad libitum) (Fig. 1) [1]. The rats were deprived of food for $18 \mathrm{~h}$ before the experiment, but had free access to water (control group) or the $40 \%$ solution of fructose (experimental groups). The initial and final body weights in all animals were recorded by an RN 10C13U, 100 g-10 kg, 


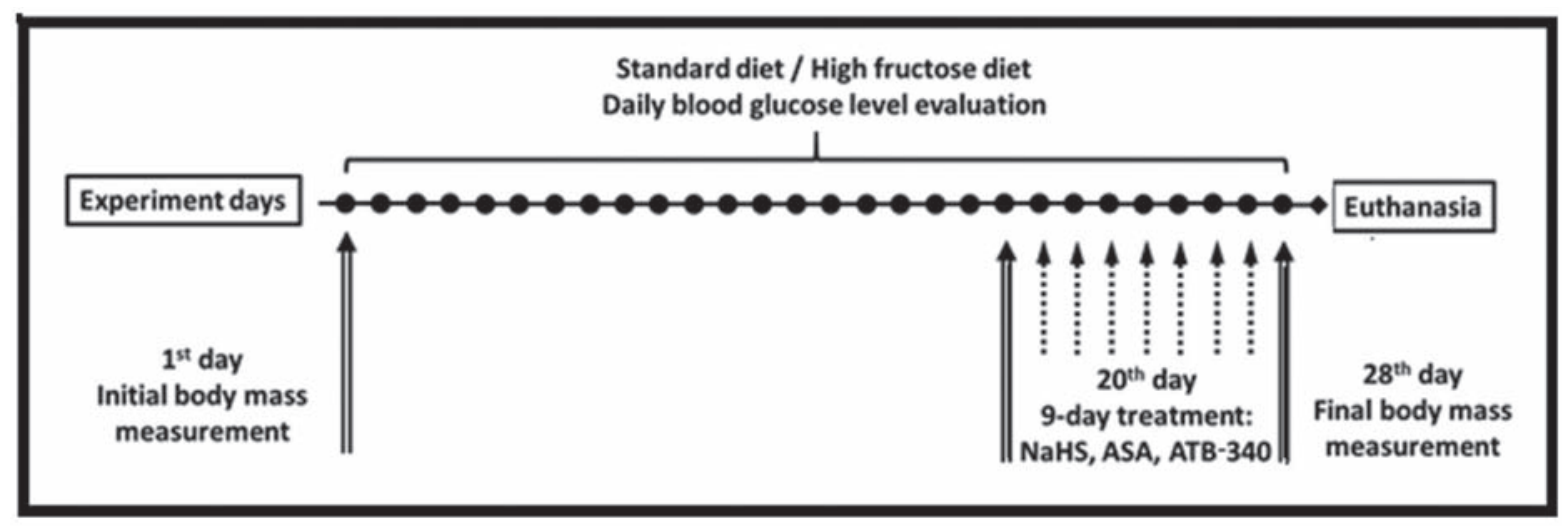

Fig. 1. The design of the study. ASA - aspirin; ATB-340 - $\mathrm{H}_{2} S-A S A$, the $\mathrm{H}_{2} \mathrm{~S}$-releasing derivative of ASA; NaHS - sodium hydrosulfide

\pm 5 g (Vagar, Kyiv, Ukraine). Rat blood glucose concentrations were measured daily after $15 \mathrm{~h}$ of fasting (18:00 - 9:00) by a glucometer (Achtung TD-4207, Munich, Germany) using a blood sample from the tail vein. The obtained data in each group was compared at the beginning and end of the study, and with the results from control rats.

Rats in the control group (group $1, n=6$ ) were fed SD and treated intragastrically (i.g.) with vehicle (1.0 ml of saline). Experimental groups (groups 2-8, $n=6$ per group) received 28 days of hypercaloric HFD, with or without stress on the 29th day of the study and had different treatments. For investigation of adaptive changes of AM, stress was induced by following the model of Takagi and Okabe (1968) that involves $3.5 \mathrm{~h}$ exposure to water-immersion restraint stress (WIS) on the last day (29 $9^{\text {th }}$ day) of the study [19, 20]. During WIS induction the rats were placed in restraint cages and immersed vertically to the level of the xiphoid process in a water bath at $23^{\circ} \mathrm{C}$ (for $1.5 \mathrm{~h}$ ). Experimental groups (groups 2-8) included rats fed by HFD and treated i.g. for 9 days ( $20^{\text {st }}-28^{\text {th }}$ day of study) as follows (Fig. 1): group 2) vehicle (saline $1.0 \mathrm{ml} /$ day); group 3) NaHS, $5.6 \mathrm{mg} /$ $\mathrm{kg}$ /day; group 4) saline $1.0 \mathrm{ml} /$ day with induction of WIS; group 5) NaHS, $5.6 \mathrm{mg} / \mathrm{kg} /$ day and induction of WIS; group 6) conventional ASA, $10 \mathrm{mg} /$ $\mathrm{kg}$ /day and induction of WIS; group 7) $\mathrm{H}_{2} \mathrm{~S}$-ASA (ATB-340), $17.5 \mathrm{mg} / \mathrm{kg} /$ day and induction of WIS; and group 8) combination of ASA, $10 \mathrm{mg} / \mathrm{kg} / \mathrm{day}$ and NaHS, $5.6 \mathrm{mg} / \mathrm{kg} / \mathrm{kg} /$ day and induction of WIS. The administration of NaHS and $\mathrm{H}_{2} \mathrm{~S}$-ASA (ATB340) was performed at doses tested by J.L. Wallace, 2015-2017 [16-18].

After the $29^{\text {th }}$ day, the rats were deeply anesthetized with an intramuscular injection of ketamine
(60 mg/kg; Biovet, Bila Tserkva, Ukraine), and after that, the mesentery was resected. After thoroughly washing with saline, sections of the mesentery were taken for histological examination and the establishment of macroscopic signs of damage. Samples for morphological cellular and subcellular analysis by electron microscopy were obtained from the mesenteric wall associated with the small intestine.

For the cellular and subcellular analysis, the mesenteric material was fixed with a $2 \%$ solution of osmium oxide $\left(\mathrm{OsO}_{4}\right) \mathrm{eV} 0.10 \mathrm{~mol} / \mathrm{l}$ phosphate buffer. Subsequently, mesenteric material was processed according to generally accepted methods. Ultrathin sections (30-60 nm) were made on an UTMTP-3M ultramicrotome (Sumy Electron Optics PKF, Sumy, Ukraine) and after Reynolds staining, they were photographed and examined using an electron microscope UEMV-100K (Sumy Electron Optics PKF, Sumy, Ukraine ) at a magnification of 4000 and 10000x. Histological analyses were performed by at least two independent people blinded to the identity of the samples. About 15 different cells in each sample were analyzed per rat.

At the end of the study, blood samples from all rats were evaluated for biomarkers of oxidative damage and $\mathrm{H}_{2} \mathrm{~S}$ biogenesis in triplicate for each animal. The level of thiobarbituric acid reactive substances (TBARS) was determined by reaction with thiobarbituric acid. The resulting lipid peroxidation products form a red-stained complex which is extracted with butanol. The test tubes containing the serum were cooled at room temperature and maximum light absorbance was measured at $535 \mathrm{~nm}$ using a UV-visible spectrophotometer (Apel PD-303, Saitama, Japan) [22]. CBS activity was evaluated by $\mathrm{H}_{2} \mathrm{~S}$ production in the reaction of condensation of L- 
homocysteine with L-cysteine ( $\beta$-replacement). CSE activity was evaluated by $\mathrm{H}_{2} \mathrm{~S}$ production in the reaction of desulfuration of L-cysteine to pyruvate $(\alpha$, $\beta$-elimination). The activities of CBS and CSE were assessed by the accumulation of sulfide anion from the reaction with N,N-dimethyl-para-phenylenediamine in incubation media, which could provide optimal conditions for enzyme activity determination [22, 23]. Maximum light absorbance was measured at $670 \mathrm{~nm}$ using the Apel PD-303 UV-visible spectrophotometer.

Statistical analysis. The Statistica 7.0 software program (Statsoft, Round Rock, Texas, USA) was used for all mathematical and statistical analyses. Results are expressed as mean \pm SEM (standard error of the mean). For each quantification, at least $n=6$ was used for each group. Data were assumed to be abnormally distributed (non-Gaussian) and statistical analyses were performed. A paired Mann-Whitney U-test was used for comparisons of paired treatments between two groups. One-way ANOVA using Dunnett's test was performed to determine any statistically significant differences between experimental groups and vs the control group. $P$ values $<0.05$ were considered statistically significant differences.

\section{Results}

First, to confirm the effect of HFD on the mesentery adipocyte specific functions and physiological peculiarities, we investigated general changes in the rats. Exposure to HFD during 28 days resulted in no statistically significant differences in body weight of rats in the experimental groups vs the control rats fed SD. Fig. 2 shows the plasma glucose profiles from rats fed with SD or HFD. Rats consuming HFD for 28 days had significantly higher blood glucose levels than control rats fed SD $(6.2 \pm 0.40 \mathrm{mM} / \mathrm{l}$ vs $5.6 \pm 0.20 \mathrm{mM} / \mathrm{l}, P<0.05$

Next, we investigated the effect of HFD on macroscopic changes in the mesentery, as well as expression of cellular and subcellular changes in $\mathrm{AM}$ and their adaptive changes during WIS and from NaHS pre-treatment. During the macroscopic assessment, there were no changes in the mesentery. For the sake of comparision, in control rats fed SD the histological components of the mesentery belong to the mesothelioma and connective tissue, and are represented by collagen fibrils, fibroblasts, where there were populations of adipocytes, vessels, neural bundle, and lymphatic tissue (Fig. 3). In that group AM was represented by the oval shaped adipocytes which exceeded the size of fibroblasts by several times (Fig. 3, A). Their cytoplasm is filled with a single drop of fat with characteristic vacuoles. Narrow sections of the cytoplasm in the periphery contain common organelles, which are dominated by mitochondria (Fig. 3, B).

Mesenteric adipocytes in the rats fed HFD for 28 days and treated with vehicle (saline) were barrel-shaped with signs of extensive hypertrophy and fat fragmentation, with formation of a few small fat drops (Fig. 4, A). The infiltration by macrophages between adipocytes was noted. Visceral type capillaries were surrounded by collagen fibrils, fibro-

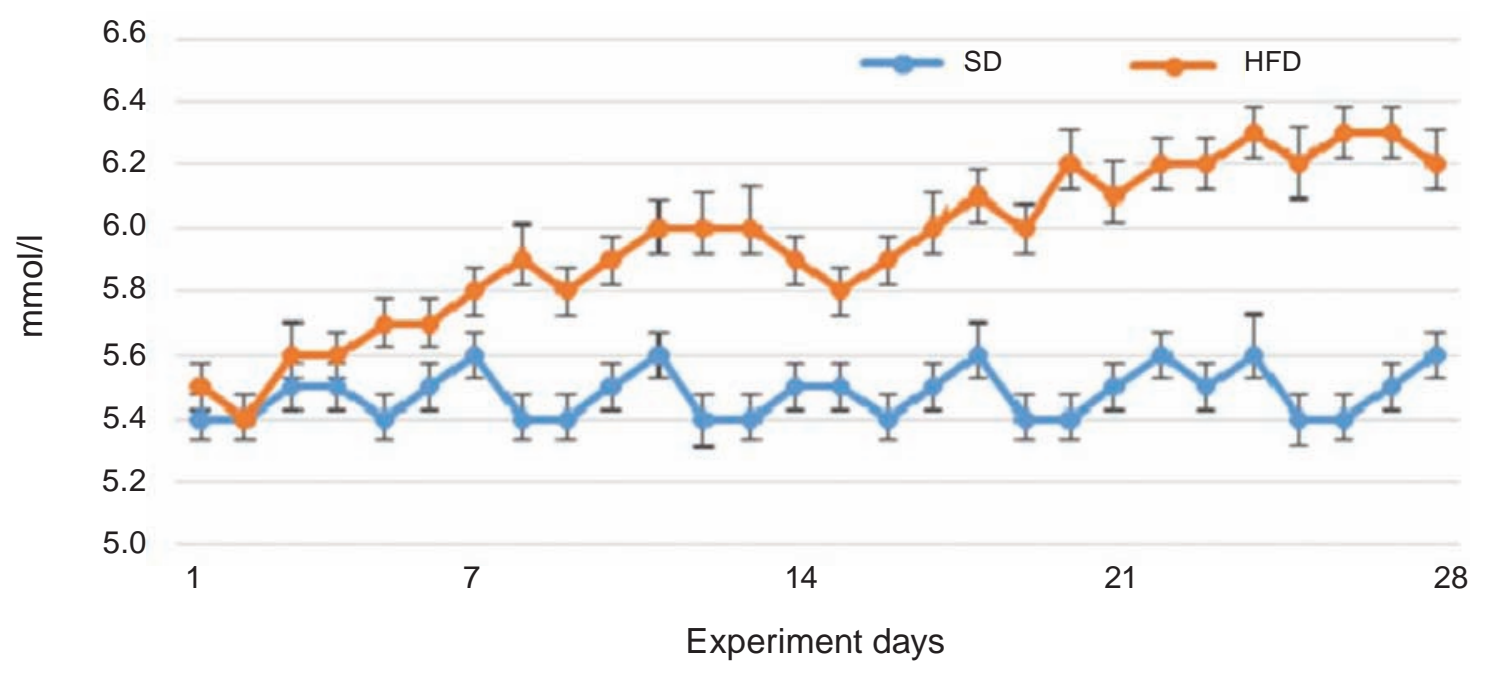

Fig. 2. Blood glucose levels in rats fed standard diet (SD) or high fructose diet (HFD) during 28 days. Results are given as mean $\pm \operatorname{SEM}(n=6)$ 

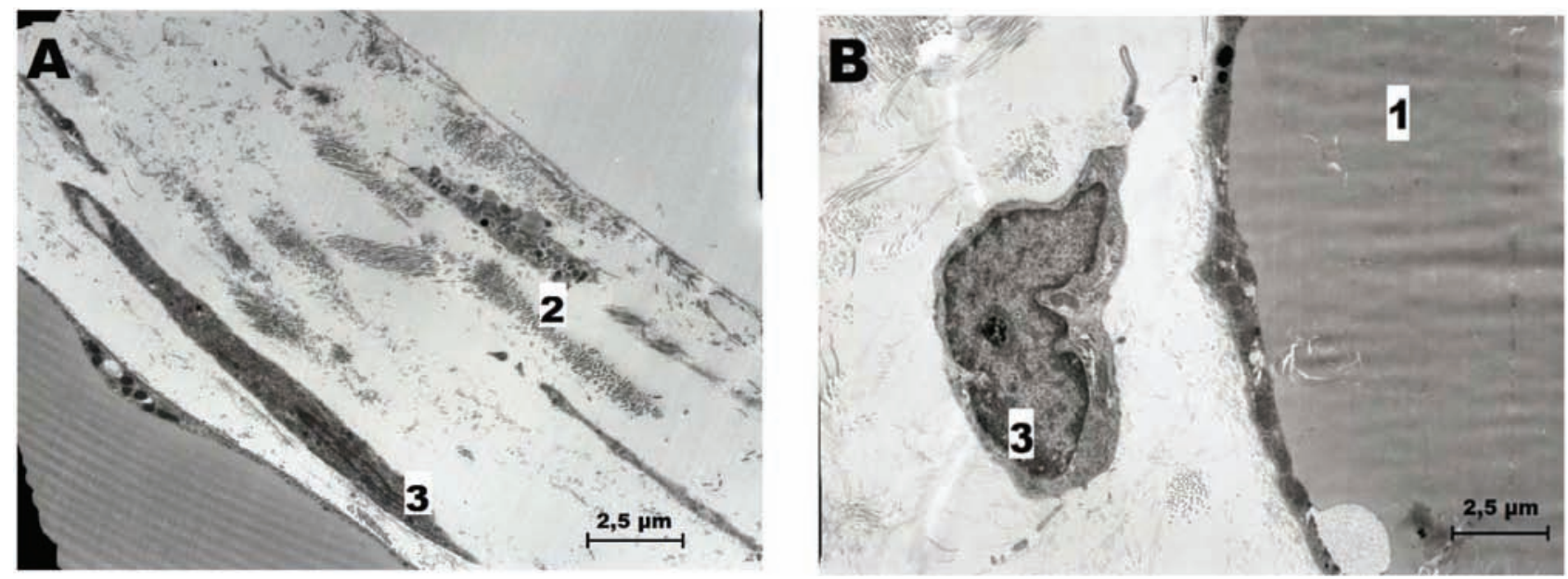

Fig. 3. Transmission electron microscopy of the mesentery of control rats fed SD. (A) Fragment of the connective tissue of the mesentery with the presence of collagen fibrils (2) and fibroblasts (3). (B) Among the connective tissues there are fibroblasts (3) and an adipocyte (1). Magnification 4000x

blasts, and macrophages. Microvilli were presented on the apical endothelial surface, pinocytotic vesicles, dilated endoplasmic reticulum cisterns and individual lysosomes, and the nucleus with signs of apoptosis were identified in the cytoplasm. The lumen of the hemocapillary was filled with blood plasma and erythrocytes were in the lumen of hemocapillaris (Fig. 4, A).

Around adipocytes were randomly located collagen fibrils. The peripheral region of the cytoplasm of the adipocyte had signs of cytoplasmic edema and electron-dense mitochondria with an electrondense matrix. Some mitochondria were elongated or had a ring-like structure. Digital shaped invagination of AM plasmalemma was detected (Fig. 4, B). Mesenteric adipocytes in the rats fed HFD for 28 days and treated with vehicle and exposed to WIS (Fig. 4, $C, D$ ) had signs of fat defragmentation, with fat droplets released outside. There were damaged hemocapillaries with signs of endothelial destruction, uncovered basal membrane and edema between endothelium and underlaying basal membrane.

Mesenteric connective tissue is shown in Fig. 5, including a white adipocyte from rat fed HFD and exposed to WIS and pretreated with NaHS, the combination treatment of NaHS with ASA, and $\mathrm{H}_{2} \mathrm{~S}$ ASA (ATB-340). Nine days of pretreatment with NaHS before WIS induction reduced signs of mesenteric endothelial dysfunction in rats fed HFD (Fig. 5, A) but the AM had vacuolated cytoplasm around the fat droplet, cytoplasmic edema, mitochondrial hypertrophy and densification of the matrix, as well as many disintegrated mitochondria with signs of self-destruction (Fig. 5, B). In rats fed HFD and pretreated with the combination of NaHS and ASA the signs of mesenteric endothelial dysfunction were less expressed, and mesenteric collagen fibrils were visible around the oval-shaped adipocytes that were without signs of damage (Fig. 5, C). Pretreatment with $\mathrm{H}_{2} \mathrm{~S}$-ASA (ATB-340) reduced signs of mitochondrial dysfunction in the AM and the nucleus of adipocytes had a small amount of heterochromatin and was surrounded by an intact nucleolemma.

Pretreatment with the combination of NaHS and ASA caused cytoprotective effects in the AM. The AM were oval-shaped and normal-sized, despite the presence of several small fat droplets in the peripheral cytoplasm (Fig. 5, C). $\mathrm{H}_{2} \mathrm{~S}$-ASA (ATB340) treatment caused cytoprotective effects and attenuated mitochondrial dysfunction (Fig. 5, D).

An effect of HFD on the serum TBARS levels in rats from experimental groups in comparison to the control group fed SD was observed (Fig. 6). In HFD-fed rats treated with saline the levels of TBARS increased by $20 \%$ over results of the control group $-3.04 \mu \mathrm{M} / \mathrm{l}(P<0.05)$. In rats exposed additionally to WIS, TBARS levels were twice elevated vs the control SD-fed group $(P<0.001)$. Treatment for 9 days with $\mathrm{H}_{2} \mathrm{~S}$ compounds ( $\mathrm{NaHS}, \mathrm{H}_{2} \mathrm{~S}$-ASA or ASA+NaHS) showed a downward trend of lowering the level of TBARS in experimental groups exposed to HFD and WIS. The administration of $\mathrm{H}_{2} \mathrm{~S}$-ASA decreased the levels of TBARS by approximately half $(P<0.05)$, NaHS - by $30 \%(P<0.001)$ and 

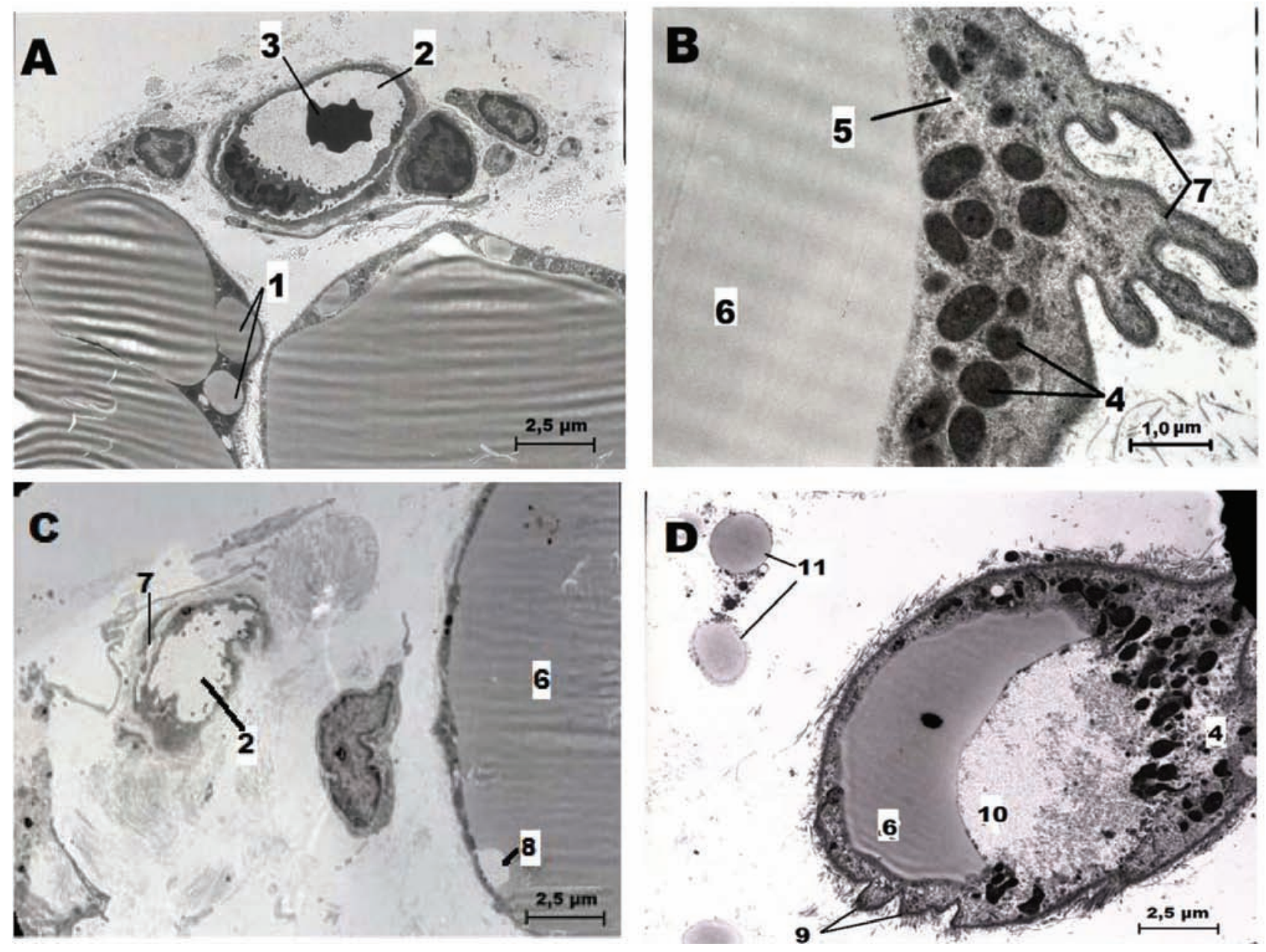

Fig. 4. Transmission electron microscopy of connective tissue from mesentery of rats fed HFD and treated with vehicle (saline $1.0 \mathrm{ml} /$ day) (A), (B) without induction of water-immersion restraint stress (WIS) and (C), (D) with WIS induction. (A) Fat cells with signs of fat fragmentation, with small drops of fat in the cytoplasm of adipocytes (1). Erythrocytes (echinocytes) (3) are present in the lumen of hemocapillaries (2) 4000x magnification. (B) Fragment of an adipocyte. Located around the large fat droplet (6) is vacuolated cytoplasm (5) with a large number of ring-like mitochondria (4) and digital-shaped invagination of the plasmalemma (7). 10000x magnification. (C) Fragment of adipocyte with signs of fat defragmentation, large fat droplet (6), releasing fat droplets outside (8), damaged hemocapillary with signs of endothelial destruction (2), and edema between endothelium and basal membrane (7), 4000x magnification. (D) Fragment of adipocyte with the sign of digital-shaped invagination of the plasmalemma (9), cytoplasm (10) with a large number of self-destructive and ring-like mitochondria (4) located peripherally and large fat drop (6) defragmentation, releasing fat droplets outside (11), 4000x magnification

the combination of ASA and NaHS - by $20 \%$ compared to vehicle (saline) treated rats $(P<0.001)$. Interestingly the level of TBARS during ASA pretreatment was increased by $15 \%$ compared to the vehicle (saline) group which had TBARS $=6.41 \mu \mathrm{M} / \mathrm{l}$ $(P<0.001)$.

In the last part of the study, we investigated the effects on CSE and CBS activities of pre-treatment with $\mathrm{H}_{2} \mathrm{~S}$ compounds in HFD-fed rats, and with and without WIS induction. Serum CSE and CBS activities in mesentery tissue were up-regulated by HFD $25 \%$ over control $(2.0 \mathrm{nmol} / \mathrm{mg} \cdot \mathrm{min}$ protein, $P<0.05)$ and in rats treated with NaHS - 38\% vs the saline-treated group $(P<0.05)$ (Fig. 7). A similar effect was demonstrated for the rat groups exposed to acute stress (WIS). Except for rat groups with $\mathrm{H}_{2} \mathrm{~S}$ pre-treatment by NaHS, $\mathrm{H}_{2} \mathrm{~S}$-ASA (ATB-340), or $\mathrm{ASA}+\mathrm{NaHS}$ where CSE and CBS were up-regulated 

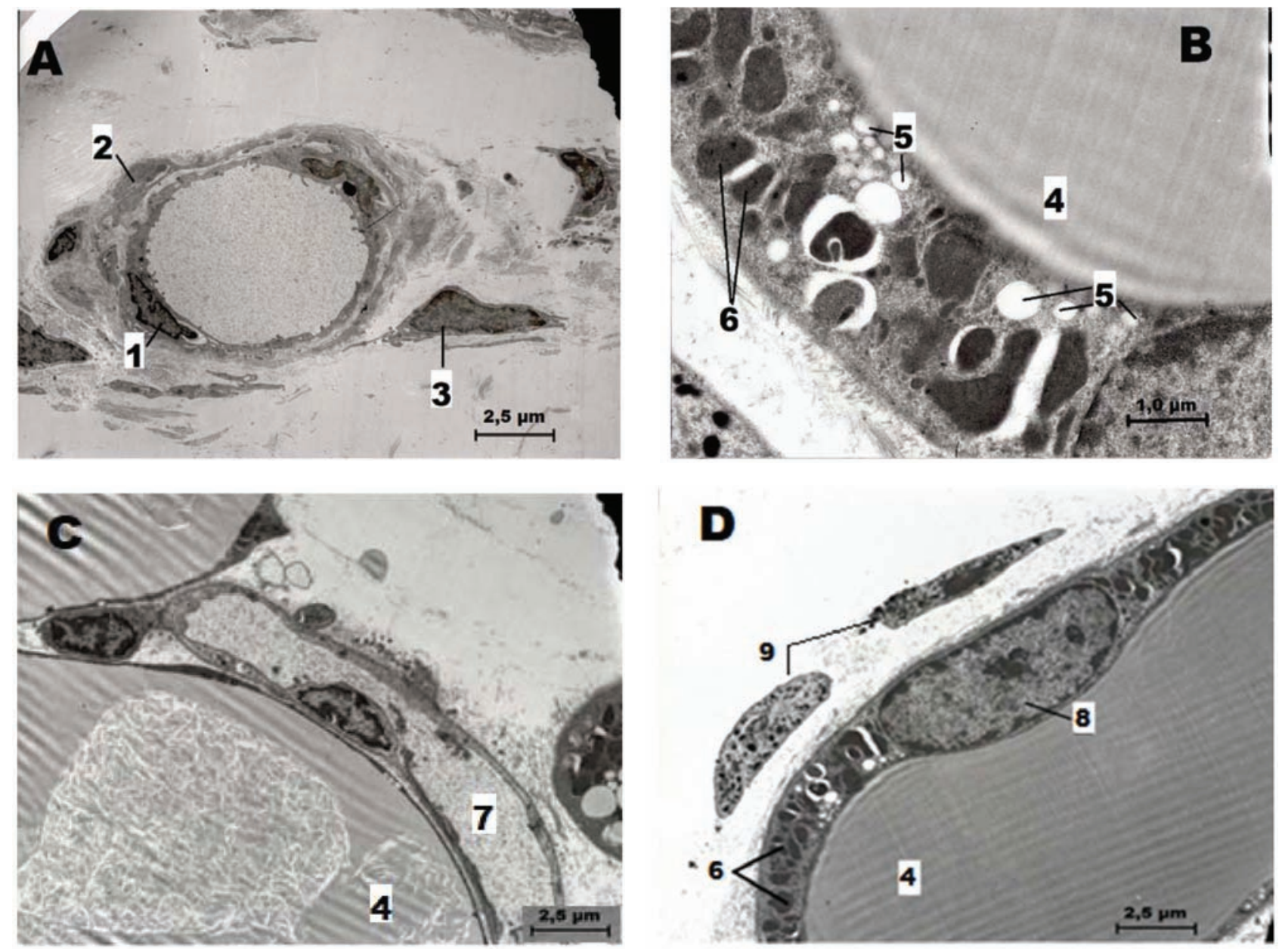

Fig. 5. Transmission electron microscopy of mesenteric connective tissue from rats fed HFD and (A) (B) exposed to water-immersion restraint stress (WIS) and NaHS, (C) the combination of NaHS and aspirin (ASA), and (D) $\mathrm{H}_{2} \mathrm{~S}$-ASA (ATB-340). (A) Visceral hemocapillary. Endotheliocyte (1), pericyte (2) and fibroblast (3) are visible. 4000x magnification; (B) Mesenteric white adipocyte. Large fat droplet in adipocyte (4), fat droplets (5) and mitochondria with signs of self-destruction (6) are visible. 10000x magnification; (C) Fragment of adipocyte, with large fat droplet in adipocyte (4) and hemocapillary (7). Magnification 4000x; and (D) Fragment of adipocyte with peripherally located mitochondria showing signs of self-destruction (6), cell nucleus (8) with heterochromatin, and mast cell (9). A large fat droplet in an adipocyte (4) is also seen. Magnification 4000x

$(P<0.001)$, the expression of CSE and CBS during acute stress and saline or ASA pre-treatment were down-regulated $(P<0.05)$. Next, we compared the effect of ASA vs $\mathrm{H}_{2} \mathrm{~S}$-ASA (ATB-340) on serum CSE and $\mathrm{CBS}$ activities and significant increases were observed in the group treated by the hybrid compound $\mathrm{H}_{2}$ S-ASA of approximately $20 \%(P<0.001)$.

\section{Discussion}

Translational research with "obesogenic" environmental factors such as HFD has shown that animal models play an important role in the identification and testing of cytoprotective compounds for RAT, and this step is essential for identification of targets for pathogenesis-based anti-obesity drugs [24-26]. The HFD model, as a high-caloric diet, provides the development of postprandial hyperglycemia that, in turn, promotes excess oxidation caused by nutrients and release of mediators which induce oxidative stress related to metabolic responses [27]. Therefore, growing evidence indicates that the HFD model mimics the natural history of the RAT in disease events as well as the pathophysiological characteristics of human obesity $[8,28]$. It is triggered by hyperglycemia via multiple pathways linked to oxidative stress and could cause 


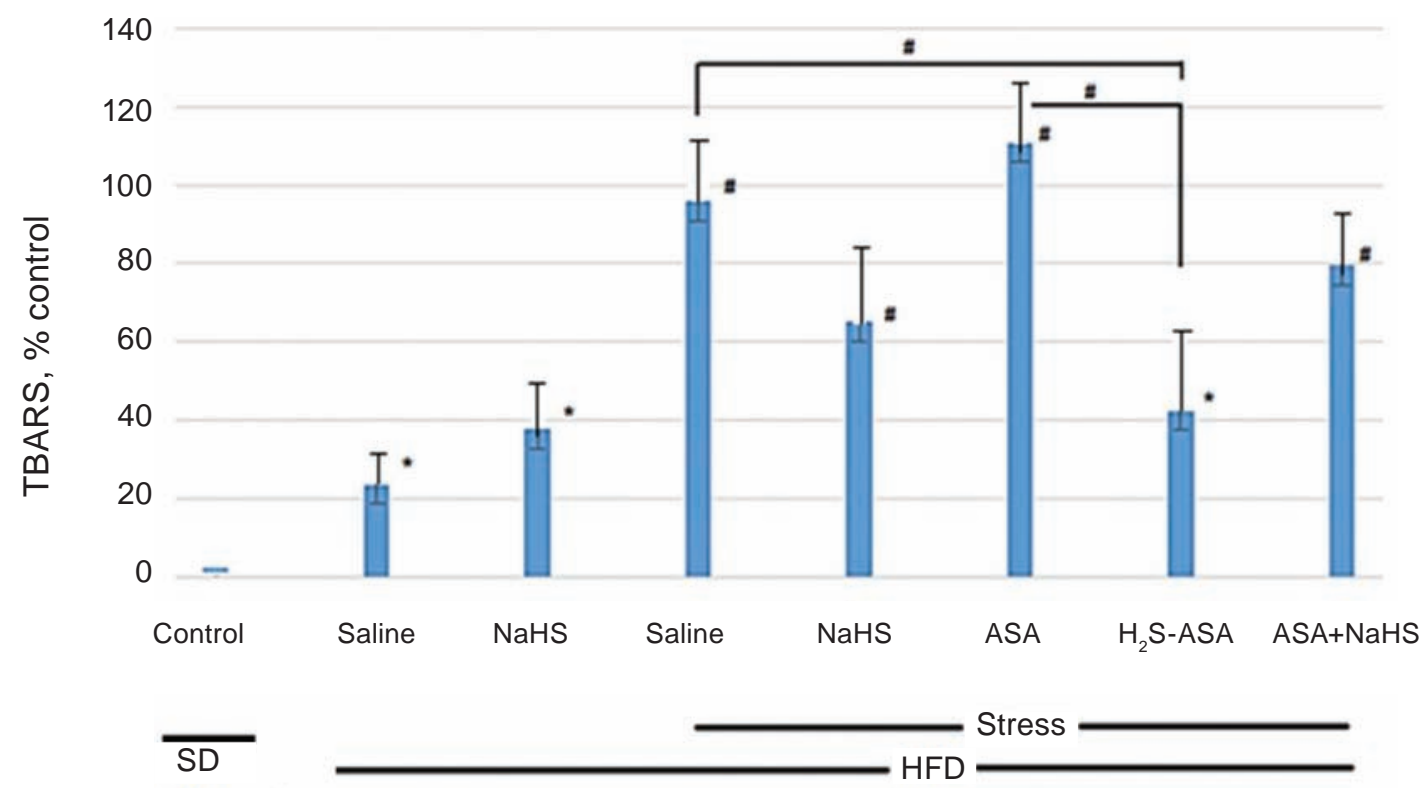

Fig. 6. The levels of thiobarbituric acid reactive substances (TBARS) in rats fed standard diet (SD) and treated with vehicle (saline) (control group) or fed high fructose diet (HFD) with and without induction of water-immersion restraint stress (WIS) and treated with vehicle (saline), NaHS, aspirin (ASA), $\mathrm{H}_{2} \mathrm{~S}$-ASA (ATB-340), or combination of $\mathrm{NaHS}+A S A$. Results are shown as mean $\pm S E M ; * P<0.05$ significantly different from control group fed $S D ;{ }^{*} P<0.001$ significantly different from control group fed $S D ;(n=6)$

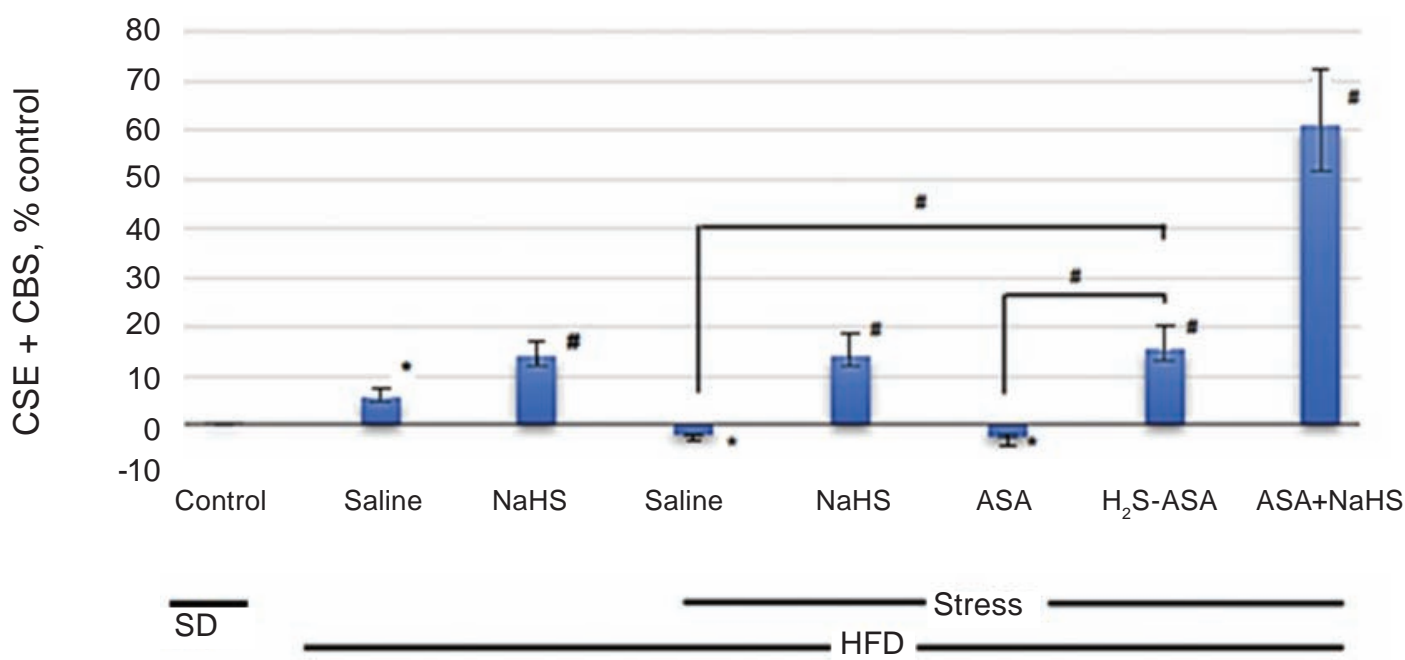

Fig. 7. Changes of cystathionine- $\gamma$-lyase (CSE) and cystathionine- $\beta$-synthase (CBS) activities in rats fed with standard diet (SD) and treated with vehicle (saline) (control group) or high fructose diet (HFD) rats treated with saline, NaHS, aspirin (ASA), $\mathrm{H}_{2} \mathrm{~S}$-ASA (ATB-340), or the combination of NaHS+ASA. Results are shown as mean $\pm S E M ;{ }^{*} P<0.05$ significantly different from control group fed $S D ;{ }^{*} P<0.001$ significantly different from control group fed $S D ;(n=6)$

accelerated aging, cardiovascular disease, diabetes mellitus type 2, non-alcoholic fatty liver disease, and cancer [28, 29].

Scientists Calvin Coffey and Peter O'Leary at the University of Limerick in Ireland recently changed the conventional interpretation of the mesentery as being the addition of the intestine [7] which was characterized by fragmentation, to the most updated notion, when it was found that the mesentery is a complete single organ, originating 
from the upper root mesentery, and then continuously attached to the intestine in the direction from the duodenum to the rectum, with inherent capacity for single organ physiological functions and pathological processes [6]. Mesenteric adipocytes are the main site for the formation of visceral white adipose tissue, which acquire signs of toxicity, but whether RAT occurs in AM during short-term 4-week HFD had not been studied. Our study showed that RAT in mesentery in from HFD-fed rats is the result of an adaptive excess of carbohydrates, which cause mitochondrial production of free radicals that become triggers for oxidative stress, which is then accompanied by endothelial dysfunction in mesentery adipocytes (Fig. 4).

Several scientific groups confirm that mitochondria, important organelles in different cells, play a crucial role in the maintenance of redox balance, energy biosynthesis, antioxidant activities and cellular homeostasis $[5,15,30]$. Recent studies have implicated the activation of mitochondrial dysfunction in the pathogenesis of several comorbid pathologies (non-alcoholic fatty liver disease, cardiovascular disease, obesity) associated with RAT, as it contributes to the perpetuation of the oxidative stress and metaflammation (a metabolic inflammatory process) $[4,19]$. Moreover, according to the recent view, AM has worse blood capillary supply and intrinsically low antioxidant enzyme defense that make it vulnerable to hypoxia and free radical damage, the main triggers for oxidative stress injuries [31]. Our results showed that the AM from HFD-fed rats were hypertrophic, a condition considered by researchers to be indicative of oxidative stress and adipocyte dysfunction $[2,8]$. We defined that 4 weeks of fructose nutritional overload affects AM. Several small fat droplets were inside in the AM, some mitochondria were elongated or had ring-like structure, and the basal membrane of hemocapillaries had changed.

These findings mean that HFD causes modification of AM and can serve as a trigger for formation of self-destructive mitochondria and mitochondrial dysfunction which are signs of early stages of oxidative stress that could be a target for therapy. In this regard, potent anti-oxidative substances, such as exogenous $\mathrm{H}_{2} \mathrm{~S}$ compounds have potent cytoprotective properties [16, 32, 33]. To demonstrate the action of exogenous $\mathrm{H}_{2} \mathrm{~S}$ compounds on AM upon HFD and WIS exposure, we used administration of NaHS, a novel $\mathrm{H}_{2} \mathrm{~S}$-releasing derivate of ASA $\left(\mathrm{H}_{2} \mathrm{~S}\right.$-ASA [ATB-340]), or a combination of ASA and NaHS.
We find a beneficial cytoprotective effect of therapy with $\mathrm{NaHS}$ or $\mathrm{H}_{2} \mathrm{~S}-\mathrm{ASA}$ vs saline treatment, as well as their anti-radical effect on the serum TBARS level and up-regulating effect on CSE and CBS activities. However, NaHS-mediated treatment in HFD-fed rats was less effective than $\mathrm{H}_{2} \mathrm{~S}-\mathrm{ASA}$ (ATB-340), which has additional antioxidant and cytoprotective effects on cytotoxic products of the arachidonic cycle [16].

Our results are consistent with the results obtained by other researchers [34, 35]. Therefore, we can conclude that exogenous $\mathrm{H}_{2} \mathrm{~S}$ compounds can abolish oxidative damage and mitochondrial dysfunction in adipocytes and endothelial malfunction in the rat mesentery. A similar effect was found in other studies [36, 37] and our study, which focused on cellular and subcellular changes in AM. It seems surprising that the effective influence of the hybrid $\mathrm{H}_{2} \mathrm{~S}$-ASA (ATB-340) is relatively better than NaHS or ASA+NaHS. This phenomenon could be explained by the relatively low anti-oxidative activities of NaHS and ASA on the excess of reactive oxygen species produced by HFD and WIS.

\section{Conclusions}

These findings in this animal study suggest that 4 weeks of carbohydrate overload are sufficient to contribute to the cellular changes of the mesentery related to oxidative stress, endothelial destruction, and mitochondrial dysfunction in AM. Exogenic administration of compounds which increased $\mathrm{H}_{2} \mathrm{~S}$ biosynthesis confirms the important role of $\mathrm{H}_{2} \mathrm{~S}$ for mesenteric cellular survival, especially for endotheliocytes and adipocytes against HFD-induced injury by decreased overproduction of the biomarker of oxidative damage TBARS. High expression of activities in CSE and CBS pathways in biosynthesis of H2S as the result of 9 days of exogenous NaHS treatment were associated with reduced mesenteric destructive ultrastructural changes (endothelial dysfunction, defragmentation of fat drops and accumulation of dysfunctional mitochondria) in rats fed HFD. Cytoprotection of AM during $\mathrm{H}_{2} \mathrm{~S}$-ASA (ATB-340) treatment leads to decreased cytotoxicity induced by the combination of HFD and stress in comparison to the disruptive effect of conventional ASA, as well as by the combination of NaHS and ASA. The molecular mechanism for this effect of $\mathrm{H}_{2} \mathrm{~S}$-ASA potentially comes from the presence of both $\mathrm{H}_{2} \mathrm{~S}$ and NSAID abilities to activate anti-oxidant activity. Our data provides a theoretical basis for effects of intervention by exogenous $\mathrm{H}_{2} \mathrm{~S}$ compounds which could be an ef- 
fective tool for minimizing the AM injury according to the postprandial hyperglycemia response.

Study limitations: In our study of the influence of HFD on mitochondrial dysfunction in adipocytes of mesentery we collected and presented data about cellular ultrastructural changes of mesenteric connective tissue and adipocytes. For a more detailed investigation of AM mitochondrial defects, the following approaches would be helpful: surveillance, immuno-coupled electron microscopy by spectral confocal microscopy and measurement of mitochondrial thiosulfate-dithiol sulfurtransferase activity (i.e., acts as an important mitochondrial factor for anti-oxidative stress functions).

Conflict of interest. Authors have completed the Unified Conflicts of Interest form at http://ukrbiochemjournal.org/wp-content/uploads/2018/12/ coi_disclosure.pdf and declare no conflict of interest.

Acknowledgment. We thank Cedars-Sinai Medical Center's International Research and Innovation in Medicine Program, the Association for Regional Cooperation in the Fields of Health, Science and Technology (RECOOP HST Association) for their support of our organization as a participating Cedars-Sinai Medical Center - RECOOP Research Centers (CRRC).

Funding. OR received DHLNMU support and this publication is based upon scientific work at the Physiology Department of DHLNMU "Investigation on systemic and paracrine control mechanisms in homeostasis and functional and metabolic indexes upon adaptation to extreme factors by different origin” (2016-2021, 0116U004510).

Author Contributions. Conceived and designed the experiments: OZ. Performed the experiments: OR, NZ, OZ. Analyzed the data: OR, NZ, OZ, JLW. Contributed to the writing of the manuscript: OR, OZ, JLW.

\section{ЕКЗОГЕННИЙ СІРКОВОДЕНЬ ЗАПОБІГАЕ ПОШКОДЖЕННЮ БРИЖІ, ПОВ'ЯЗАНОГО 3 ФРУКТОЗО-ІНДУКОВАНИМИ ПОРУШЕННЯМИ ШЛЯХОМ ГАЛЬМУ ВАННЯ ОКИСНОГО СТPECУ}

О. Ревенко ${ }^{1 \bowtie}$, Н. Заічко ${ }^{2}$ Дю. Л. Уоллес ${ }^{3}$, О. Заячківська

${ }^{1}$ Кафедра нормальної фізіології, Львівський національний медичний університет імені Данила Галицького, Україна;

${ }^{2}$ Кафедра біологічної та загальної хімії, Вінницький національний медичний університет ім. М. І. Пирогова, Вінниця, Україна; ${ }^{3}$ Кафедра фізіології та фармакології, Університет Калгарі, Канада; 凶e-mail: wersus35@gmail.com

Патологічні зміни адипоцитів брижі (АМ), спричинені дієтою з високим вмістом фруктози (HFD), є джерелом багатьох супутніх захворювань. Менше з тим, їх патогенез залишається мало дослідженим і не існує ефективних препаратів, які б запобігали ремоделюванню АМ. Нещодавні дослідження показали, що сірководень $\left(\mathrm{H}_{2} \mathrm{~S}\right)$ має сильну цитопротекторну дію. Метою даного дослідження було вивчити чинники, що лежать в основі патологічних змін АМ щурів, які перебували на HFD та дослідити дію $\mathrm{H}_{2} \mathrm{~S}$ у разі екзогенного застосування. Дорослих самців щурів розділили на групи, група на стандартній дієті (SD, контрольна група) та експериментальні групи, що перебували на HFD, та які піддавалися впливу гострого водно-імерсійної стресу (WIS). Вплив на AM екзогенного гидросульфида натрію (NaHS, 5,6 мг/кг/день протягом 9 днів) та збагаченого $\mathrm{H}_{2} \mathrm{~S}$ гібридного аспірину (ASA) $\left(\mathrm{H}_{2} \mathrm{~S}\right.$-ASA [ATB-340], 17,5 мг/кг/день) у даному досліджені порівнювали 3 дією звичайного аспірину ASA (10 мг/кг/день). Адаптивні зміни 
АМ оцінювали на субклітинному рівні за допомогою електронної мікроскопії. Концентрацію глюкози в сироватці, рівні реактивних субстанції тіобарбітурової кислоти (TBARS), та активність цістатіон- $\gamma$-ліази (CSE) і цістатіон$\beta$-синтази (CBS) було досліджено біохімічними методами з використанням спектрофотометрії. У тварин із HFD застосування NaHS спричиняло захисний вплив на АM, ендотеліальні та субендотеліальні структури мікросудин брижі порівняно до щурів, що отримували плацебо, i мали ознаки ендотеліальної та мітохондіальної дисфункції, пошкодження АМ. Використання $\mathrm{H}_{2} \mathrm{~S}$-ASA характеризувалось захисною дією на AM у тварин із HFD та WIS, зниженням вмісту TBARS у крові та підвищенням активності CSE та CBS. Дія дієти з високим вмістом фруктози впродовж 4-х тижнів є достатньою причиною для виникнення окисного пошкодження AM, появі мітохондріальної дисфункції та змін ендотелію. $\mathrm{H}_{2} \mathrm{~S}$ відіграє важливу роль у виживанні адипоцитів брижі за умов окисного стресу, спричиненого HFD, за рахунок зменшення продукції TBARS та мітохондріальної дисфункції. Застосування $\mathrm{H}_{2} \mathrm{~S}$ може сприяти появі нового підходу у лікуванні ожиріння.

К люч ю в і слова: гідроген сульфід $\left(\mathrm{H}_{2} \mathrm{~S}\right)$, реактивні субстанції тіобарбітурової кислоти (TBARS), цистатіон гамма-ліаза (CSE), цистатіон бета-синтаза (CBS), окисний стрес, адипоцити, брижа, мітохондрії.

\section{References}

1. Bezpalko L, Gavrilyuk O, Zayachkivska O. Inflammatory response in visceral fat tissue and liver is prenatally programmed: experimental research. J Physiol Pharmacol. 2015: 66(1): 5764.

2. Mancuso P, Bouchard B. The impact of aging on adipose function and adipokine synthesis. Front Endocrinol. 2019; 10: 137.

3. Kuprinenko N. Endocrine and neurological diseases: problems of comorbidity. Int $J$ Endocrinol. 2018; 14(6): 610-616.

4. Corsello T, Komaravelli N, Casola A. Role of hydrogen sulfide in NRF2- and sirtuindependent maintenance of cellular redox balance. Antioxidants. 2018; 7(10): 129.

5. Hotamisligil GS. Inflammation, metaflammation and immunometabolic disorders. Nature. 2017; 542(7640): 177-185.
6. Argikar AA, Argikar UA. The mesentery: an ADME perspective on a 'new' organ. Drug Metab Rev. 2018; 50(3): 398-405.

7. Coffey JC, O'Leary DP. The mesentery: structure, function, and role in disease. Lancet Gastroenterol Hepatol. 2016; 1(3): 238-247.

8. Cinti S. Adipose organ development and remodeling. Compr Physiol. 2018; 8(4): 13571431.

9. Rivera ED, Coffey JC, Walsh D, Ehrenpreis ED. The mesentery, systemic inflammation, and Crohn's disease. Inflamm Bowel Dis. 2019; 25(2): 226-234.

10. Cao X, Ding L, Xie ZZ, Yang Y, Whiteman M, Moore PK, Bian JS. A review of hydrogen sulfide synthesis, metabolism, and measurement: is modulation of hydrogen sulfide a novel therapeutic for cancer? Antioxid Redox Signal. 2019; 31(1): 1-38.

11. Cui J, Liu L, Zou J, Qiao W, Liu H, Qi Y, Yan C. Protective effect of endogenous hydrogen sulfide against oxidative stress in gastric ischemiareperfusion injury. Exp Ther Med. 2013; 5(3): 689-694.

12. Giuffrè A, Vicente JB. Hydrogen sulfide biochemistry and interplay with other gaseous mediators in mammalian physiology. Oxid Med Cell Longev. 2018; 2018: Article ID 6290931.

13. Mishanina TV, Libiad M, Banerjee R. Biogenesis of reactive sulfur species for signaling by hydrogen sulfide oxidation pathways. Nat Chem Biol. 2015; 11(7): 457-464.

14. Olson KR, Gao Y, Arif F, Arora K, Patel S, DeLeon ER, Sutton TR, Feelisch M, CorteseKrott MM, Straub KD. Metabolism of hydrogen sulfide (H2S) and production of reactive sulfur species (RSS) by superoxide dismutase. Redox Biol. 2018; 15: 74-85.

15. Smirnov A, Comte C, Mager-Heckel AM, Addis V, Krasheninnikov IA, Martin RP, Entelis N, Tarassov I. Mitochondrial enzyme rhodanese is essential for $5 \mathrm{~S}$ ribosomal RNA import into human mitochondria. J Biol Chem. 2010; 285(40): 30792-30803.

16. Wallace JL, Blackler RW, Chan MV, Da Silva GJ, Elsheikh W, Flannigan KL, Gamaniek I, Manko A, Wang L, Motta JP, Buret AG. Antiinflammatory and cytoprotective actions of hydrogen sulfide: translation to therapeutics. Antioxid Redox Signal. 2015; 22(5): 398-410.

17. Wallace JL, de Nucci G, Sulaieva O. Toward more GI-friendly anti-inflammatory medications. 
Curr Treat Options Gastroenterol. 2015; 13(4): 377-385.

18. Wallace JL, Motta JP, Buret AG. Hydrogen sulfide: an agent of stability at the microbiomemucosa interface. Am J Physiol Gastrointest Liver Physiol. 2018; 314(2): G143-G149.

19. Takagi K, Kasuya Y, Watanabe K. Studies on the drugs for peptic ulcer. A reliable method for producing stress ulcer in rats. Chem Pharma Bull (Tokyo). 1964; 12(4): 465-472.

20. Takagi K, Okabe S. The effects of drugs on the production and recovery processes of the stress ulcer. Jpn J Pharmacol. 1968; 18(1): 9-18.

21. Wallace J, Pshyk-Titko I, Muscara MN, Bula N, Pavlovsky Y, Gavriluk E, Zayachkivska O. Influence of hydrogen sulfide-releasing aspirin on mucosal integrity of esophageal and gastric mucosa. Proc Shevchenko Sci Soc. Med Sci. 2015; 43(27): 63-74.

22. Zaichko N, Pentyuk N, Melnik A. The formation of hydrogen sulfide in the organs of rats. Med Chem. 2009; 11(4): 7-13.

23. Dombkowski RA, Russell MJ, Olson KR. Hydrogen sulfide as an endogenous regulator of vascular smooth muscle tone in trout. Am J Physiol Regul Integr Comp Physiol. 2004; 286(4): R678-R685.

24. Gomaa AA, Farghaly HSM, El-Sers DA, Farrag MM, Al-Zokeim NI. Inhibition of adiposity and related metabolic disturbances by polyphenol-rich extract of Boswellia serrata gum through alteration of adipo/cytokine profiles. Inflammopharmacology. 2019; 27(3): 549-559.

25. Jack BU, Malherbe CJ, Mamushi M, Muller CJF, Joubert E, Louw J, Pheiffer C. Adipose tissue as a possible therapeutic target for polyphenols: A case for cyclopia extracts as anti-obesity nutraceuticals. Biomed Pharmacother. 2019; 120: 109439.

26. Ng LT, Gruber J, Moore PK. Is there a role of $\mathrm{H}_{2} \mathrm{~S}$ in mediating health span benefits of caloric restriction? Biochem Pharmacol. 2018; 149: 91100.

27. Weidinger C, Hegazy AN, Siegmund B. The role of adipose tissue in inflammatory bowel diseases. Curr Opin Gastroenterol. 2018; 34(4): 183-186.

28. Untereiner $\mathrm{A}, \mathrm{Wu} \mathrm{L}$. Hydrogen sulfide and glucose homeostasis: a tale of sweet and the stink. Antioxid Redox Signal. 2018; 28(16): 14631482.

29. Kabil O, Banerjee R. Redox biochemistry of hydrogen sulfide. J Biol Chem. 2010; 285(29): 21903-21907.

30. McGonigle P, Ruggeri B. Animal models of human disease: challenges in enabling translation. Biochem Pharmacol. 2014; 87(1): 162-171.

31. Ma X, Lee P, Chisholm DJ, James DE. Control of adipocyte differentiation in different fat depots; implications for pathophysiology or therapy. Front Endocrinol. 2015; 6: 1.

32. Rose P, Moore PK, Zhu YZ. H2S biosynthesis and catabolism: new insights from molecular studies. Cell Mole Life Sci. 2017; 74(8): 13911412.

33. Van Dingenen J, Pieters L, Vral A, Lefebvre RA. The H2S-releasing naproxen derivative ATB346 and the slow-release $\mathrm{H}_{2} \mathrm{~S}$ donor GYY4137 reduce intestinal inflammation and restore transit in postoperative ileus. Front Pharmacol. 2019; 10: 116.

34. Nakajima T. Roles of sulfur metabolism and rhodanese in detoxification and anti-oxidative stress functions in the liver: responses to radiation exposure. Med Sci Monit. 2015; 21: 1721-1725.

35. Schrattenholz A, Groebe K, Soskic V. Systems Biology Approaches and Tools for Analysis of Interactomes and Multi-target Drugs. In: Yan Q. (eds) Systems Biology in Drug Discovery and Development. Methods in Molecular Biology (Methods and Protocols), vol 662. Humana Press, Totowa, NJ, 2010: 29-58.

36. d'Emmanuele di Villa Bianca R, Fusco F, Mirone V, Cirino G, Sorrentino R. The Role of the Hydrogen Sulfide Pathway in Male and Female Urogenital System in Health and Disease. Antioxid Redox Signal. 2017; 27(10): 654-668.

37. Magierowski M, Magierowska K, HubalewskaMazgaj M, Sliwowski Z, Pajdo R, Ginter G, Kwiecien S, Brzozowski T. Exogenous and endogenous hydrogen sulfide protects gastric mucosa against the formation and time-dependent development of ischemia/ Reperfusion-induced acute Lesions progressing into deeper Ulcerations. Molecules. 2017; 22(2): 295. 